Studies in English Drama and Poetry Vol. 3

\author{
Estella Antoaneta Ciobanu
}

Ovidius University

\title{
Staging Transgression Stories in the Later Middle Ages: Divine Fiat, Truth and Justice in the N-Town Play of the Annunciation
}

\begin{abstract}
The Middle English Annunciation plays dramatise a heterological encounter whose stakes, Mary's willing collaboration with God in the salvific project, can be brought to bear on both the Christian meta-narrative and the condition of women in late medieval Western society. Despite their edifying thrust, however, the Annunciation plays also stage transgression by referencing or intimating a breach of law, whose more overt forms range from recounting the story of Adam and Eve's transgression of the divine commandment, coded in theological discourse as original sin, to the enactment of the Incarnation as transgression of natural law by divine fiat, an authorised transgression (Prosser) implicitly coded as transcendence and dramatised in the $\mathrm{N}$ Town Play 11 in a spectacular stage direction with a heavy dogmatic burden.

I use the notions of truth regimes (Foucault) and truth formulae (Weir) to investigate the play's less obvious unauthorised transgression (Prosser), manifest in the implicit interrogation of the Christian truth regime, i.e., the Lucan and Incarnational orthodoxy grounding the script, as it emerges from the divine debate on human redemption. Furthermore, reading the N-Town heavenly parliament with Anselm of Canterbury's Cur Deus Homo points out the entanglements of kyriarchal truth regimes in power and the ensuing violence of representation (Armstrong and Tennenhouse). I argue that the play's brief suggestion that the deity is overly revengeful appears itself transgressive of both contemporary theology and the secular ordo. This secondary discourse - a form of glossolalia (Certeau) - not only disrupts the naturalisation of human justice modelled on divine self-consistency but also intimates the self-legitimising drive of patriarchal discourses of worldly auctoritas.
\end{abstract}

The Middle English plays of the Annunciation dramatise a heterological encounter ${ }^{1}$ whose stakes, a woman's willing collaboration with the deity for the redemption of humanity (cf. Lk. 1.26-38), could be brought to bear on the Christian meta-narrative at large. On the face of it, the fifteenth-century N-Town play The Parliament of Heaven; The Salutation and Conception ${ }^{2}$ and other

${ }^{1}$ I use the term "heterological" to denote encounters with the Other as studied by Michel de Certeau, here specifically the human-divine encounter between the Virgin Mary and archangel Gabriel as the emissary of the Godhead. Certeau's heterological studies implicitly address a power differential conducive to the differential possibility of knowledge.

${ }^{2}$ The N-Town plays are perhaps the most puzzling collection of drama compiled in medieval England, whose provenance and performance auspices are still a matter of indeterminacy as any overview of the literature (Gibson; Fletcher; Sugano) will show. A manuscript collection of 
English plays on the topic highlight Mary's ancillary readiness to be instrumental in the divine plan, ${ }^{3}$ contingent upon what theological discourse deemed one of the most mysterious ways of the Lord (I use the word advisedly) and which medieval drama brought to the fore: the Incarnation.

It would seem counterintuitive, therefore, to argue that such a play could at the same time stage transgression. However, transgression stories - referencing or suggesting a breach of law - do appear. On the one hand, the Lucan Annunciation story ushers in the project of undoing the effects of the original transgression, coded as sin, which all English Annunciation plays unfailingly mention. Nonetheless, the very Incarnation occurs through God's and, by divine fiat, Mary's transgression of natural law - divinely appointed to separate mortals from the Godhead - in a discourse that scripts and stages the event as Goddecreed and prophetically announced to the humans. ${ }^{4}$ On the other hand, the $\mathrm{N}$ Town Play $11^{5}$ appears itself transgressive when the dialogue of the characters

booklets whose compilation by an educated scribe probably started in 1468 , the N-Town plays evolved in several stages - where the second layer, the devotional Mary Play, includes the Annunciation play - and then was revised slightly later by two other scribes. I use here the text and line numbering of the N-Town Play 11 in Douglas Sugano, based on Stephen Spector's critical edition, The N-Town Play: Cotton MS Vespasian D.8 (1991); the spelling, however, follows Gerard NeCastro's version. I have accordingly retained the Middle English characters "p" (thorn, cf. modern "th") and " $z$ " (yogh, cf. modern "gh" or " $y$ "), as well as the dialectal (East Anglian) "x" (cf. modern "sh") in the modal verb "shall." Quotations from plays, including the other three English mystery cycles, identify the collection by abbreviation: $N T$ for $N$-Town, $Y$ for York, C for Chester, $\mathrm{T}$ for Towneley, followed by the play's number in the edition cited and then the line number(s).

${ }^{3}$ All the English plays' (intertextual) web of doctrinal explication regarding the necessity and conditions of possibility of the Incarnation corresponds to a gospel narrative which ends with Mary's meek submission to the heavenly decree, a role, however, that had already been devised for her by divine fiat, as prophecy shows (Isa. 7.14), and earlier still, in the creation of Eve as Adam's adiutorium (Gen. 2.18), viz. "help" (Douay-Rheims) or "helper" (New King James Version), for womankind. In the N-Town play more compellingly than in the other Annunciation plays, Gabriel instructs Mary that the Godhead is depending on her active assent (NT 11.285-88): not only is the salvific plan a matter of collaboration but Mary is expected - cf. abydyth (264), both anxiously waited for and intended - to act in accordance with the divine design (261-64). For all its dramatic context with a strong theological inflection, the script's use of "entent" (NT 11.262; $M E D$, s.v. "entente") - by Gabriel, to reference Mary's position - is imbued with the legalistic force of the contractual relation envisaged in the embassy to Mary.

${ }^{4}$ Such blatant transgression is understated in theological discourse and the Annunciation plays as the impossibility that a virgin should give birth, duly poised against undeniable divine omnipotence (cf. Lk. 1.37). The Annunciation narrative, therefore, subtly re-codes this form of transgression as transcendence: as both virgin mother and the only one human to be assumed bodily to heavens upon "dormition" to be exalted as heavenly Queen, Mary has sublimely transcended her mortal lot. By comparison, Elijah (2 Kings 2.11) and Enoch (Gen. 5.24; Heb. 11.5), also assumed into heaven, yet before death, are in no other way exceptional bodily.

${ }^{5}$ Titles have been added to the N-Town plays, in this case Parliament of Heaven, Salutation and Annunciation, by the editor Stephen Spector. The episode of the heavenly parliament of Play 
embodying divine traits implicitly interrogates the Christian truth regime and its imbrication in power.

A brief introduction of my major theoretical leanings is paramount before I look at the double articulation of the plot and analyse the heavenly parliament as discursive transgression. One aspect of transgression which I address is what in a different context Diane Prosser calls a "transgression of language" (3), i.e., stepping beyond the linguistic constraints embedded in different types of discourse and thereby dangerously blurring their boundaries, here the theological and dramatic discourses. However, transgression behaviour and biblical stories thereof are coded linguistically in a circular definition: they are identified (textualised) as infraction of the law, the law itself pre-existing its breach, e.g., the Adamic sin (Gen. 2-3), or, alternatively, being constituted in its wake, e.g., Cain's fratricide (Gen. 4). I adopt Prosser's concepts of "authorised" and "unauthorised transgression" $(2-4,14-15)$ to harness their paradox-ridden force, respectively to explicate the drama of the Incarnation in the Virgin's body in a phallogocentric theology "girded in structures of oppressive relations" (Prosser 14) and to capture the theological as well as social doubts expressed in the language of stage drama.

My discussion of the N-Town characters Truth and Justice reads the corresponding Middle English concepts with Michel Foucault's notion of "truth regimes." Foucault uses "truth" to refer not to content but to the rules ascertaining the assignment of truth value to statements, subject to contentious negotiations whereby "the true and the false are separated and specific effects of power attached to the true" (132). Arguably, truth as "a system of ordered procedures for the production, regulation, distribution, circulation and operation of statements" (Foucault 133) is a general condition of the formation and development not only of politico-economic regimes but also of religious systems, as the history of the fight for orthodoxy in medieval Christendom proves. In her emendation to the Foucauldian notion, Lorna Weir contends that a truth regime mediates reality by means of "truth formulae": "how things are made to appear, how they come to be represented, and how the relation between things and words is formulated" (368). ${ }^{6}$

If truth regimes and truth formulae collude with power to mediate reality, then there is ample room for misrepresentation. In arguing this, I take my cue

11 is not mentioned at all in the Banns (157-69) attached at some point during the compilation of the N-Town plays to describe their content. Evidence of the plays' renumbering suggests that the Banns' later revision intended, though unsuccessfully, to accommodate the Marian material newly added to the play (Sugano).

${ }^{6}$ Truth formulae can be used heuristically. Weir proposes, to "distinguish differing types of truth: veridical, governmental, symbolical, and mundane" (369; emphasis added). Such heuristic use is paramount to an investigation of medieval drama as an arena of dynamic intersections of discourses, from conflicting or emerging truth games to the intersection of discourses and natural bodies. 
from Nancy Armstrong and Leonard Tennenhouse's contention that what is often represented as violence may conceal "violence of representation":

[Violence] which is "out there" in the world ... [is] opposed to that which is exercised through words upon things in the world, often by attributing violence to them. But . . the two cannot in fact be distinguished, at least not in writing. . . . [V]iolent events are not simply so but are called violent because they bring together different concepts of social order. (Armstrong and Tennenhouse 9)

Accordingly, interpretation should be aware of how "representations . . . suppress the emergence of their own discursive power where fiction reveals it" (Armstrong and Tennenhouse 9) so as not to replicate the discursive strategies of the texts and context under scrutiny.

Unlike the Flood or Passion plays, the English Annunciation plays thematise anything but overt violence; nonetheless, their faithful rendition of the Lucan story is complicit in the age's politics of "en-gendering" (cf. de Lauretis $240)^{7}$ social hierarchy and legitimising patriarchal injustice as God-sanctioned. The specific "battle about the truth" (Foucault 132) in the English Annunciation plays and its staging as transgression in the N-Town Play 11 offer a glimpse into the violence of representing Mary - and by implication women - as agentive in a narrative of kyriarchal ${ }^{8}$ imposition of gender roles. ${ }^{9}$

Since in N-Town the typical grounding of the Annunciation plays' Incarnation in the grand plan of salvation ${ }^{10}$ hinges upon the heavenly parliament,

${ }^{7}$ According to Teresa de Lauretis (240-45), violence is not only engendered in representation as violence of representation, but it is specifically created along gender lines, "engendered," since within the enunciative modality constructed by Western phallogocentrism theoretical pronouncements are always already assumed to be made by a male(-sexed) subject.

${ }^{8}$ Elisabeth Schüssler Fiorenza has coined the terms "kyriarchy," "kyriocentrism," "kyriarchal" so as to designate the patriarchal system of domination, itself mediated by andro-kyriocentric (malemaster dominated) language, without assuming merely gender dualism (11n28, 14n31). As an analytic category, kyriarchy "articulates a more comprehensive systemic analysis of empire, in order to underscore the complex interstructuring of domination, and to locate sexism and misogyny in the political matrix - or better, 'patrix' - of a broader range of dominations" (14n31).

${ }^{9}$ The scope of this paper does not allow me to address issues of medieval drama authorship. Despite their heavy religious burden, the English biblical cycles "encode the piety of people rather than that of clerics" (Clopper 169); although "the clerical voice is apparent to varying degrees in the extant texts," it "does not systematically promote" the current clerical educational agenda for the laity to which it responds $(208,210)$, since the "dramas tend toward the eschatological and apocalyptic but primarily are penitential" (210). Such penitential issues, however, were addressed in accordance with a patriarchal Christian discourse whose dual ontology and gender-biased positive prescriptions have often been remarked but which Clopper overlooks completely.

10 In certain plays this is achieved through a rehearsal of God's intent $(T 10.17-75 ; N T$ 11.33-213); in others, an intermediary expositor figure plays the same role (Y 12.1-144). The 
the play is uniquely positioned to address the mechanics of the kyriarchal retributive logic newly refashioned as redemptive. Unlike the other Annunciation plays, N-Town features a multilayered framing system which is self-validating: its core, the Annunciation, illuminates as well as fulfilling the first episode of the heavenly parliament, itself preceded by Contemplacio's prologue, a speech which provides the theological and intercessory framework for the Incarnation in a circular argument. ${ }^{11}$

Two details in the Annunciation episode are salient for my investigation: a stage direction calling for the spectacular enactment of the mystery of conception (NT 11.292) and a juridical term (304) used by Mary immediately afterwards. The theatrical truth formula mediating the Incarnational doctrine in the stage direction overwrites the theologically sanctioned equation of divinity and light with the Marian Theotokos dogma ${ }^{12}$ :

Here pe Holy Gost discendit with iij bemys to oure Lady, the Sone of be Godhed nest with iij bemys to pe Holy Gost, the Fadyr godly with iij bemys to pe Sone. And so entre all thre to here bosom. (NT 11.292)

Here the Holy Ghost descends with three beams to Our Lady, the Son of the Godhead next with three beams to the Holy Ghost, and the Father Godly with three beams to the son, and so enter all three into her bosom. ${ }^{13}$

Unsurprisingly, immediately prior to this moment Gabriel exalts Mary as the lantern of light (292), viz. the Chōra - receptacle and container - of Christ-theLight-of-the-World (Jn. 8.12, 9.5).

Chester "wrightes playe" starts its composite plot with the Salutation and Annunciation episode (C 6.1-48), which is announced in the Sybil's prophecy and by portents that the Expositor explains to the audience.

${ }^{11}$ Such circularity of argument was indebted to the Christian theologians' hermeneutic emphasis upon typology or prefigurement in the structure of the Bible (Auerbach).

12 The ecumenical council Ephesus III (431 CE) proclaimed that as Christotokos ("the Bearer/Mother of Christ"), Mary was also Theotokos ("the Mother of God"), a doctrine endorsed by the Council of Chalcedon (451) in the definition of Christ's two natures in one person, viz. the hypostatic union (Placher 83-84). However, the very Theotokos dispute in the early Church arguably addressed not so much Mary, the woman whose body made the Incarnation possible, but abstractly and sublimely Jesus' dual nature beyond the implications of corporeality proper.

13 Though theologically overembodied, the conception (NT 11.292, stage direction) creatively overlays the Johannine ego lux in mundum veni ("I am come, a light into the world"; Douay-Rheims, Jn. 12.46), with the Nicene-Constantinople creedal doctrine of filioque stating the procession of the Holy Ghost from both the Father and the Son (Schaff 65-67). The stage effects may have struck the spectators with an overwhelming suggestion of light-cum-power that persuaded them to devotion, as the critics rightly insist, yet in every sense must have overpowered both Mary and vicariously women in the audience. 
Mary's speech describing the bliss of conception (NT 11.293-309) provides yet another truth formula, which illuminates the overall legalistic framework of the play. ${ }^{14}$ During her scholarly espousal of Chalcedonian/Athanasian orthodoxy (cf. Schaff 62-63, 69), Mary prays to God for a special prerogative for her baby by virtue of his special paternity: "It is worthy zoure son now my son have a prerogatyff" (NT 11.304). Encompassing as it does both the notion of a special right and its beneficiary ( $M E D$, s.v. "prērogātīf'), the play's usage of prerogatyff is consistent with the medieval juridical compass of the term, yet in so doing it obliterates the role of power differentials in defining the prerogative: as the $M E D$ entry (s.v. "prērogātîf") wryly suggests, the primary sense of "prerogative" denotes "the absolute discretionary power possessed by a royal personage, a sovereign right, royal prerogative." What the entry does not mention is that this absolute discretionary power, implicitly the flip-point of tyranny, is delimited vis-à-vis God's in a circular definition which begs identifying the source of this privilege and how it disenfranchises others. Once envisaged as a salient theological descriptor of the deity, whether in the N-Town play or anywhere in medieval discourse, as in Anselm of Canterbury's Cur Deus Homo ("Why God Became Man" [1099]; hereafter $C D H$ ), "prerogative" can implicitly be deployed to ground and legitimise all types of special rights practically exclusively as a male preserve.

The truth formulae encapsulated in the two phrases above illustrate the incipient constitution of a new truth regime already started in the parliament of heaven. ${ }^{15}$ While its unfolding is illustrative of the medieval construal of order as hierarchy (cf. Duby), the parliament is hardly an exclusive landmark for the heavenly realm and the tenuous decision-making regarding human salvation. At stake is the propriety of showing mercy to a fallen humanity damned to eternal punishment, debated by several divine and spiritual characters: Virtutes (the "Virtues," an angelic order), the Psalmic four daughters of God, viz. Veritas ("Truth"), Misericordia ("Mercy"), Justicia ("Righteousness"), Pax ("Peace"), ${ }^{16}$

${ }^{14}$ Ambiguously close to intimating orgasmic bliss though it is, the painless bliss which Mary describes to Gabriel after being overshadowed by the Holy Ghost (NT 11.305-06) is anticipated by Spiritus Sanctus and moreover offered as a token of truth telling (211-12) in a truth game that will not only reveal the truthfulness of prior discourse, viz. the vetero-testamentary prophecies of the coming of the Messiah, but also radically alter the truth regime by which the faithful are to abide if they are to earn their salvation.

${ }^{15}$ It has become apparent by now that Mary is merely the mouthpiece of the clerical/patriarchal malestream and that she is made to comply meekly with anything decreed for her to do. This comes, ironically, in accordance with the meaning of the Middle English noun parlemente played up in Stephen Spector's title, which suggests as much the debate the spectators are privy to and the manmade institution within the English body politic responsible for decision-making.

${ }^{16}$ A widespread occurrence in Christian literature, the debate between the four daughters of God - Truth, Mercy, Justice and Peace - derives from Psalm 85 (NKJV). 
and the Godhead, viz. Pater ("God the Father"), Filius ("the Son") and Spiritus Sanctus ("the Holy Ghost"). First Virtues and later Mercy intercede with God the Father on behalf of humans for "mercy" (NT 11.40, 47, 75-80), to the discomfiture of Truth and Justice. The Virtues' petition to God to have pity on His creature (43, 46), now repentant (44), immediately meets with a favourable answer, which is symptomatic of the play's penchant for highlighting a preordained state: God's speech opens with a quote from the Vulgate Psalm 11.5 (NKJV, Ps. 12.5), followed by the English version thereof (48a-c, 49-51), to proclaim that "Tyme is come of reconsyliacyon" (52). However, as Truth challenges God's decision to annul His early sentence, Mercy immediately intercedes for the salvation of humanity, only to stir Justice to side with Truth: not only does Justice rebuke Mercy for the "abhomynabyl presumpcyon" (98) that the reputed (99) "ryghtwysnes of God hath no diffynicyon ("limits")" (100), but she moreover avers that humanity cannot be redeemed. Countering Justice's self-definition with her own, to the effect that "The mercy of God is withowtyn ende" (112; cf. NKJV, Ps. 118.1-4), Mercy reprimands her sister for her revengeful disposition (105), in an exchange whose violence escalates until Peace urges the contenders to trust God's wisdom to judge the matter (124-25). God the Son intervenes to remind them, drawing implicitly on the notion of Adam's felix culpa, that "If Adam had not deyd" (139), the four daughters themselves would have perished (139-43); hence he envisages a second death (144) as a solution to the conundrum. Sent off into the world to seek out the one suitable for the atonement (151), the sisters look in vain (153-64) and Peace proposes that the Son should offer himself as sacrifice (165-68; cf. $C D H 2.6)$. This is also the conclusion reached within the Trinity after consultations about the salvific project (169-84), to the satisfaction of all four daughters (185-86), who kiss each other in reconciliation (187-88; cf. Ps. 85.10).

Arguably, this heavenly debate about the legalistic justification of eternal punishment for Adam's sin echoes ${ }^{17}$ the satisfaction theory first proposed by Anselm of Canterbury in Cur Deus Homo. ${ }^{18}$ Though seemingly unjust (cf. CDH

${ }^{17}$ I do not argue any direct influence of Cur Deus Homo on the N-Town Play 11, but simply suggest that Anselmian ideas could gradually be mediated to the laity through homilies. Ellen Ross briefly points to this play's "Anselmian portrayal" of God (82), but she does not develop this insight beyond identifying a "theme of juridical sacrifice" in the N-Town and York plays (84), with no comment on the juridical dimension. Likewise, possibly under the spell of Rosemary Woolf's optimistic remark about "God's burning love" in this play (qtd. in Ross 82), Ross explains away the import of vengefulness when she notes that Mercy "remind[s] her vengeful sister, Righteousness, that the eternal God may rectify eternal sin" (82).

${ }^{18}$ The Anselmian theory of satisfaction in Cur Deus Homo - undergirded by a "retributive logic" (Gorringe 369) - unfolds as an implicit polemic between the "character" Anselm and the infidels, whose "advocate" is Boso, a fellow Benedictine monk. The debt to God incurred by the sinner for a certain transgression is seemingly incommensurate because he or she needs to make 
$1.7,1.10,1.12)$, eternal punishment should be retained (NT 11.57-72, 89-104), argue Truth and Justice; only pursuing the original retributive politics will ensure, Veritas contends, that "thy trewthe, Lord, xal leste withowtyn ende" (65). Veritas ultimately claims that God should not reconsider His former decision so as to stay true to Himself forever - "to thine own self be true," as Polonius would say (Hamlet I.3.78). I would argue that the argument between Veritas, Justicia and Misericordia offers a painful insight into the undecidability, even cruelty, of truth and justice in the Christian doctrine of atonement and redemption. ${ }^{19}$ Whose truth and righteousness (justice) do the characters called Veritas/Trewth and Justicia/Ryghtwysnes embody? The issue is all the more urgent to address as the Son presents the solution in a speech opening with God's words in Jeremiah's prophetic letter to Israel, captive in Babylon (Jer. 29.11): "I thynke pe thoughtys of pes ("peace") and nowth ("not") of wykkydnes" (NT 11.137). Is the N-Town quotation a foreboding nod to the captivity of Mary, viz. Mary as an always already compliant participant as staged in the grand narrative of redemptionthrough-cosmic-transgression, or rather to the narrative of societal rules and regulations that the script's divine attributes are made ad imaginem?

Middle English "truth" (MED, s.v. "treuth") denotes primarily not factual truth, which is mostly rendered by "soth" ( $M E D$, s.v. "sōth"), but rather the social circumstances of acting in accordance with certain aspects of the selfrelation deemed positive at the time. In fact, "truth" refashions the other-relation as self-relation, specifically as concordance with a principle or (one's) essence. ${ }^{20}$ Accordingly, when the four daughters of God debate the opportunity for revoking the punishment for the Adamic sin, the N-Town play appears to evoke "truth" as an impartial administration of justice that plays out God's fidelity to His divine essence. This notion is reinforced by the Middle English noun "justice" (MED, s.v. "justīce"), whose circular logic identifies the socially-bound other-relation as ultimately signalling one's conformity with the law, on the template of the divine attribute of righteousness or justness. Nonetheless, like

restitution for having robbed God of His honour ( $C D H$ 1.11.4-10); the metaphysical "size-gap" between God and creatures is thus used to measure the seriousness of sin.

${ }^{19}$ A basically similar contention about self-truth as identity appears in the Chester Last Judgement, where the blessed are separated from the damned and the latter are claimed by the demons in accordance with the Christic promise, quoted by the First Demon (C 24.573-80, 580 stage direction): should Christ deny the demons their prey, he will prove to be as false and unrighteous as they, the demons, are (565-66, 571-72).

20 "Truth" (MED, s.v. "treuth") redefines the other-relation as fundamentally a self-relation, from constant allegiance, loyalty, devotion, a pledge thereof, and/or its performance under specific circumstances, to integrity in the performance of one's job, rectitude of character, the vaguely defined social virtue of trustworthiness and divine righteousness reified as a flesh and blood character, and likewise from the state of being innocent of an offence to the execution of judgement, the principle of justice and the quality of impartiality; it also defines statements, from factual statement to the codifying of a set of beliefs and to the assertion of the Christian faith as the Truth. 
"treuth," "rightwisnesse"21 and "wikkednes,"22 "justice" has its underside: it denotes (the act of) punishment, vengeance, retribution, thus signalling its connection with power in its destructive dimension. In openly articulating the view of a violent other-relation - so different from the modern sanitised position - while also vindicating violence within a retributive logic allegedly divinely originated, the terms deployed in the script downplay the violence of representing the sources of juridical violence and proffer instead a representation of violent justice as "fair play."

The N-Town script does not openly warrant an interpretation of God the Father as the vetero-testamentary Yahweh (cf. NT 11.52), ${ }^{23}$ or rather it does not implicate it any more than Middle English polysemy and medieval discursive practices do. Theologians throughout the Middle Ages painstakingly explicated the necessity of eternal infernal expiation for a time-bound transgression, ${ }^{24}$ as the

${ }^{21}$ Rightwisnesse overlaps, in its sense of "impartiality, justice, equity," "straightness," "uprightness," with rightnesse (from "right") and with rightfulnesse (from "rightful"), hence the "ryghtwysnes"-"ryghtffulnes" pairing in the play (NT 11.90-91). Like "right," rightwisnesse ("righteousness") covers the territory of justice and morality, of prerogatives as much as of duties, of fairness yet also of the administration of (just) punishment, hence its coding as a cardinal virtue, viz. equity, probity, and its use as a descriptor of God, especially of divine justice (MED, s.v. "right-wīsnes(se," "rightnesse," "rightfulnes(se," "right”).

${ }^{22}$ The medieval commingling of the now separate notions of morally evil conduct and punishment in wikkednesse ( $M E D$, s.v. "wikkednes(se") recalls the vetero-testamentary instances of human trials and tribulations through divine fiat in the absence of inequity, for instance, the Abraham and Job test-of-faith stories of victimisation (cf. Berger 99-107).

${ }^{23}$ Christian theologians often articulated the theological difference between their system of belief and the Jews' as one between the Christian God of Love and a vengeful Yahweh. However, feeling the need for an explanation to the Judaeo-Christian issue of divine vengeance as illustrated in the scriptural Flood, Augustine claims in his City of God that the wording is designed to make an impression on all categories of people so as to deter them from incurring sin (City of God 15.25). Or, such explanations did most likely reach the laity through preaching: John Mirk's Festial (c. 1382-90), a Middle English sermon collection intended to "instruct simple priests, not how to preach the word of God but to 'teach their parishioners all the main feasts that occur in the year" "and provide their liturgical explanation (Wenzel 64), points specifically to Augustine's commentary on the notion of divine vengeance. Arguing that God does not strike His trespasser but rather will show grace so as to convert the sinful, Mirk's preacher further insists: "[I]f God had done vengeance, anon the world had been ended many a day ago" (Mirk 565).

${ }^{24}$ Anselm was by no means the first theologian to interpret soteriology in a legalistic framework ( $C D H$ 1.14-15, 1.19-24). The duration of infernal chastisement for sin had been broached in both the Latin and the Byzantine Church at least ever since Origen, Clement of Alexandria and Jerome, as Pierre Batiffol shows: apokatastasis (or restitutio in pristinum statum 'restoration to the original condition'), a doctrine strongly opposed to by Augustine, envisaged the final restoration of all creatures, including the demons and lost souls, through the grace of salvation. In The City of God (hereafter $C G$ ), Augustine posits that "death is penal, and had its origin in Adam's sin" (13.2); with Cicero and the lex talionis (Exod. 21.24) in mind, he ponders "whether it is just that the punishments of sins last longer than the sins themselves lasted" ( $C G$ 21.11). Punishment for offences in the social world ( $C G$ 21.11) offers an argument which can be 
issue of atonement was central to the religious and secular authoritative discourses, both driven by a retributive logic, yet mainstream Christian dogma cautiously jettisoned the notion of a vengeful God. ${ }^{25}$ Still, the notion of a relentless pursuit of revenge that Veritas and Justicia advocate as divine selfconsistency does sound an alarm regarding the medieval truth regime and the role of truth formulae in the construction of subjectivity and social subjects alike, as well as questioning the truth (soth) of the theological discourse of divine justice. ${ }^{26}$

Ironically, Stephen Spector was right to call this episode a heavenly parliament: the debate is orchestrated here like a court of law, hence as the classic kyriarchal institution which regulates and censors civic life, and which can accordingly impose penalties for breaches of law. In effect, some words in the parliament episode evoke the play's legalistic framework signalled by

logically extrapolated to offences to God: by appealing to the notion of the incommensurable iniquity of contemptus, "despising the authority of God" (14.15), Augustine can countenance the indubitable "justice of the punishment (iusta damnatio) with which our first parents were visited for their disobedience" (14.5). With this, he reworks the issue of "the greatness of the first transgression, on account of which eternal punishment is due to all who are not within the pale of the Saviour's grace" (21.12) to contend that, depending on the case, punishment in the afterlife may be non-purgatorial, viz. not aimed at the remission of $\sin (21.13)$.

${ }^{25}$ In the central and late medieval Latin Church, the discourse of a merciful, loving God was just as important a strand as that of a judgemental, punishing deity. Especially the twelfth-century Cistercians, for example, Bernard of Clairvaux, William of St Thierry, Guerric of Igny, Aelred of Rievaulx, would structure their discourse around the metaphor of "Jesus as mother" and regard both Jesus' bleeding body and the spiritual nourishment provided by his teachings as "maternal"; the Cistercian maternal metaphor always correlated, however, with the image of a traditional pater figure, whether God the Father or Christ-the-Judge, administering punishment for transgressions, with whom the Virgin had to intercede on behalf of the Christians (Bynum 110-69). Accordingly, such correlative images of the Godhead would reinforce and legitimize normative gender identities and roles within a patriarchal society where "the feminine in Christ or God continues to function within the male-dominated structure" (Polinska 47).

${ }^{26}$ Notwithstanding any self-identitary concerns in this theological construct, the issue of divine wrath with and punishment of human depravity is often articulated in Middle English drama in terms of justice/vengeance irrespective of any specific biblical chronology, as is suggested in the recurrence of "vengyd" and cognate terms, for instance "spyll." The N-Town Noah articulates apprehensions about divine justice-cum-vengefulness: not only do both the Noahs (NT 4.20-22, 29-30, 136-39, 198-205) and Noah's father Lamech (191-97) envisage divine retribution for human transgression as revenge, but, in a speech which precedes God's promise of universal destruction (94-95, 101-04), Noah teaches his sons to dread God (50-51). In fact, the wording of the divine speech (103-04), alongside the recurrence of "vengeauance" $(214,227,235)$ in the survivors' post-diluvial laments, plays up the medieval conflation of views of retribution as punishment or revenge. Or, the capacity of ME "vengeance" to designate "the infliction of retributive injury" and likewise "vindictive anger" ( $M E D$, s.v. "venğeaunce") intimates the tyrannical, abusive inclination of the power-wielder, also suggested in the Chester Noah's Flood (3.139-44) and, less conspicuously, in the York Flood (9.37): the will to (and asseveration of) power equals the will to destroy, even as this is the stance of the Creator, hence a selfvalidating authority. 
Mary's use of "prerogatyff": "excepcyon" (NT 11.79) designates a "formal objection or protest entered by a defendant" (MED, s.v. "excepcioun"), while "transgressyon" (NT 11.77) ${ }^{27}$ and "offendyd" (NT 11.92) cover any infraction of divine or human law almost interchangeably, as both can designate offence as $\sin (M E D$, s.v. "transgressiŏun," "offenden").

Arguably, the very medieval topos of the debate of the four daughters of God abides by a transgressive logic, since it presumptuously posits God's conflictual self-difference, dramatised as four divine attributes, rather ad imaginem hominis. ${ }^{28}$ Such transgression of the implicit proposition of continuous self-consistency within the Godhead is compounded with the N-Town script's own transgression of theological decorum, when one of the four daughters, Misericordia, faults another one, Justicia, as being excessively revengeful: "Systyr Ryghtwysnes, ze are to vengeabyl ("too revengeful")" (105). Not only does God have a split, conflictual personality in medieval discourse, but one of the divine characters in the play is an overtly revengeful inclination, duly criticised yet finally elided, not repealed, in the event of the Incarnation. Mercy's reproach, resonant with the psalmic ring of the Son's own speech ("nowth of wykkydnes," 137), erupts much like an alternative, unruly voice, the latent "glossolalia" (Certeau) ${ }^{29}$ of emotions able to disrupt the rational discourse of truth and justice, even though, in fact, it is but a product of calculating reason within a retributive logic. Considering, however, that the God-figure of religious drama was conceivably perceived as a role-model of uprightness and benign rulership,,$^{30}$ it is remarkable that the script should have retained such disruptive lines at all, thus seemingly undoing the suppression of truth which the truth formulae deployed in the gospel and dramatic Annunciation story have painstakingly achieved.

27 Transgression here typically alludes to the Genesis story of the forbidden fruit and its deadly consequence for humanity (Gen. 3), where, however, no name is given to the offence.

${ }^{28}$ God's conflictual self-difference works somewhat in the image and likeness of the Pauline split "new man," viz. the righteous Christian striving to subject the drives of the flesh to the will of God, to whom human will should submit (Eph. 4.22-24; cf. Rom. 6.6).

${ }^{29}$ Michel de Certeau's "Vocal Utopias: Glossolalias" addresses the drama underlying speech: (hegemonic) speech is ruptured by the secondary and embodied voice of the other. Differences in modern uses of the term notwithstanding, glossolalia is poignantly a trompe-l'oreille (29), a "semblance of language" that lacks the structure of language; the tension so engendered is being played out on the border of the self, viz. as a self-other encounter. Certeau sees glossolalia at work already when something is "push[ing] up through the cracks of ordinary conversation: bodily noises, quotations of delinquent sounds, and fragments of other's voices punctuate the order of sentences with breaks and surprises" (29). Within this corporeal disruptive intrusion upon communication, then, the "major voice, while claiming to be the messenger of meaning, appears caught up in a doubling that compromises it" (30): its "double" emerges as a "scattered and secondary vocalization [that] traverses discursive expression, splicing or dubbing it" (30).

${ }^{30}$ Unsurprisingly, feminist students of Christian theology have voiced their deep suspicions relative to the representational power of the classic view of the deity (Jantzen 499). 
That mine is not an attempt to project modern concerns back onto the past is suggested by the theological and didactic currency of commentaries on the satisfaction theory in the central Middle Ages. ${ }^{31}$ From a non-theological position, it may be argued that the satisfaction theory as propounded by Anselm, for instance, naturalised the current status quo, ecclesiastic and secular law enforcement included, as divinely sanctioned, and, in doing so, it bolstered ancient and contemporary theories that power lay with the ruler, with the implication that, despite certain strictures, he (sic) thereby wielded a discretionary tool. There is a remarkable exchange in Cur Deus Homo (1.12), where monk Boso, playing the devil's advocate on behalf of the infideli, charges Christian thought of inconsistency: while the humans are taught the divine commandment to forgive their transgressors, God does not apply the same politics to His own offenders. Anselm explains it away by making vindictam facere ("to execute vengeance") God's exclusive prerogative, only to recant it on the spot:

There is no inconsistency in God's commanding us not to take upon ourselves what belongs to Him alone. For to execute vengeance belongs to none but Him who is Lord of all; for when the powers of the world rightly accomplish this end, God himself does it who appointed them for the purpose. ( $\mathrm{CDH} 1.12$; emphasis added)

Anselm here naturalises justice as a divine attribute and thereby legitimises its administration by human institutions as a divinely appointed task which implicitly emulates God's exercise of His prerogative. Vindictam facere, however, is anything but congenial to a theology of divine love as that underpinning the contemporary Cistercian doctrine of Jesus as mother.

There is the further danger that all the allegedly exclusively divine prerogatives, such as God's dignity ( $C D H$ 1.12), may also be extrapolated to worldly rulers, once vindictam facere has been. Was not God's dignity and majesty the template for the secular ruler's, and were not heresy and witchcraft elided with the crime of divine lese-majesty $?^{32}$ In fifteenth-century England, the lawyers' construct of the body politic specifically used Christ as the model for

31 Anselm's Christological atonement theory was developed in highly influential works within theological circles, e.g., Peter Lombard's and Bonaventure's Sentences, Aquinas' Summa Theologiae or John Duns Scotus' Oxford lectures (Adams 17-90). Quite tellingly for the theologians' legalistic bent, Bonaventure distinguished between vindictive punishment, appropriately inflicted on the guilty, and placating punishment, voluntarily assumed by a guiltless person on behalf of the guilty party; Bonaventure declared vicarious expiation by the innocent as better pleasing the severity of divine justice than the punishment of the guilty (qtd. in Adams 41).

${ }^{32}$ In Policraticus 4.1 (1159), John of Salisbury argues the prince's "likeness on earth of the divine majesty" and legitimises his power as God's vicarious exercise of power. Innocent III's decretal Vergentis in senium (25 March 1199) elides heresy with the crimen laesae majestatis in imperial law (Lambert 92-93). On this template, Malleus Maleficarum (c. 1486-87) identifies witchcraft as high treason against God's majesty and cites canonical precedents (Pt.1, Q1, 9D-10A). 
the king (Kantorowicz 268-71). Furthermore, as so many pronouncements by the Church or theologians emphasise, there is an inescapability of subordination to the will of God ( $C D H$ 1.15) - hence, by implication, to the will of the ruler and (his) lex. Such accruals to a doctrine that started with Augustine's free will had likely abusive consequences in the realm of the political, not least by the violence of representation implicit in the equation of (vindictive) punishment with (divinely ordained) justice.

To conclude, in the N-Town Play 11 the heavenly parliament episode not only grounds the Annunciation but especially suggests the working of the Christian truth regime in the later Middle Ages. Particularly when read with Anselm of Canterbury's Cur Deus Homo, the play seems to subvert its overall instructive program and lay bare the human view of divine justice and truth, or rather divine self-consistency in the other-relation. While it is virtually impossible to probe the likely effects such implications may have had on individual spectators, let alone on communities - after all, there is no evidence of the play's performance in any particular East Anglian locality - I cannot suspect that the script's transgressive breach of orthodoxy fell on deaf ears, ${ }^{33}$ especially considering the often heterodox religious practices in late medieval England, for instance, Lollardy. What the audience witnessed, therefore, was, at a spiritual no less than meta-discursive level, the agonistic constitution of Christianitas as body politic, ${ }^{34}$ one wherein the balance of power could at any time incline in favour of revenge, as Misericordia aptly remarks of Justicia, and wherein a vindictive truth regime would be superseded by another one, just as abusive. In other words, the old truth regime, of infinite punishment for a finite offence because of the infinite dignity of the offended party, is about to be replaced with one where the just is to atone for the unjust. Such supersession can only occur, according to Christian dogma, through an especially transgressive form of fiat, the breach of natural law. Ironically, in the N-Town Play 11, the

${ }^{33}$ The position of the two characters, Veritas and Justicia, and their symbolic role map out not only the didactic agenda of the N-Town Annunciation play but also suggest the resonance this heavenly parliament may have had on the spectators, themselves subject to justice and truth games likely to confound or even disempower them, yet - some of them - also tempted to try new truth formulae, for example, the Lollard one. Whatever impact the episode, culminating in Gabriel's embassy to Mary, had on individual spectators, it may further have been inflected by the realisation that while Mercy, one of the four daughters of God, was not much of an institutional character in real life, religious discourse to the contrary notwithstanding, Truth and Justice were the pillars of ecclesial and secular society in ways often harshly felt.

${ }^{34}$ Christianitas (Van Engen 539-52), a medieval umbrella term for the world of the Christians, their ethos and their religious-jurisdictional bond, provided a hegemonic representational model imposed by the Church for jurisdictional unity no less than for epistemological coherence. This collective body's physical-spiritual liability to attacks from both within and without, viz. from the interstitial and marginal zones of otherness, became apparent, as did its constructedness, at times of socio-political or religious unrest. 
lesser party - (a) woman - is asked to consent to this authorised transgression (Prosser 2-4, 14-15; emphasis added); in fact, she is assigned this role by the old truth regime which has projected the new one in the debate on the necessity of this transgression of divine nature and then coded it in prophecy. To the extent that the dialogic resolution of the retributive issue posits a conflictual divine persona wherein one character faults another one for being excessively revengeful, the N-Town play also stages unauthorised transgression. Such doubts regarding the stability of theo-logy are entertained in a phallogocentric drama whose transgressive figures - albeit thinly disguised - are Mary, on the one hand, and divine Truth, Justice and Mercy, on the other.

\section{Works Cited}

Adams, Marilyn McCord. What Sort of Human Nature? Medieval Philosophy and the Systematics of Christology. Aquinas Lecture. Milwaukee: Marquette University Press, 1999. Print.

Anselmi Cantuariensis. Libri Duo: Cur Deus Homo. 1857. Ed. Hugo Laemmer. Berolini: G. Schlawitz. Print.

Anselm of Canterbury. Cur Deus Homo. Trans. Sidney Norton Deane. Chicago: Open Court Publishing Company, 1903. Print.

Armstrong, Nancy, and Leonard Tennenhouse. "Representing Violence, or 'How the West Was Won.'” Introduction. The Violence of Representation: Literature and the History of Violence. Ed. Armstrong and Tennenhouse. London: Routledge, 1989. 1-26. Print.

Auerbach, Erich. "Figura." Scenes from the Drama of European Literature. Trans. Ralph Manheim. Minneapolis: University of Minnesota Press, 1984. 11-76. Print.

Augustine. St. Augustin's City of God and Christian Doctrine. Trans. Marcus Dodds. Nicene and Post-Nicene Fathers. Ed. Philip Schaff. New York: Christian Literature Publishing, 1890. Print.

Aurelius Augustinus. De Civitate Dei. Ed. B. Dombart and A. Kalb. Turnhout: Brepols, 1955. Print. Corpus Christianorum Series Latina XLVII/XIV, 1-2.

Batiffol, Pierre. "Apocatastasis." The Catholic Encyclopedia. Vol. 1. New York: Robert Appleton Company, 1907. Web. 28 Feb. 2008.

Beadle, Richard, ed. The York Plays. London: Edward Arnold, 1982. Print. York Medieval Texts 2.

Berger, Benjamin L. "On the Book of Job, Justice, and the Precariousness of the Criminal Law." Law, Culture and the Humanities 4 (2008): 98-118. Print.

Bynum, Caroline Walker. Jesus as Mother: Studies in the Spirituality of the High Middle Ages. Berkeley: University of California Press, 1982. Print.

Certeau, Michel de. "Vocal Utopias: Glossolalias." The New Erudition. Spec. issue of Representations 56 (Autumn 1996): 29-47. Print.

Clopper, Lawrence M. Drama, Play, and Game: English Festive Culture in the Medieval and Early Modern Period. Chicago: University of Chicago Press, 2001. Print.

De Lauretis, Teresa. "The Violence of Rhetoric: Considerations on Representation and Gender." The Violence of Representation: Literature and the History of Violence. Ed. Nancy Armstrong and Leonard Tennenhouse. London: Routledge, 1989. 239-58. Print.

Duby, Georges. The Three Orders: Feudal Society Imagined. Trans. Arthur Goldhammer. Chicago: University of Chicago Press, 1980. Print. 
England, George, and A. W. Pollard, eds. The Towneley Plays. 1897. London: Oxford University Press, 1966. Print.

Fiorenza, Elisabeth Schüssler. Introduction. Democratizing Biblical Studies: Toward an Emancipatory Educational Space. Louisville: Westminster John Knox Press, 2009. 1-21. Print.

Fletcher, Alan J. "The N-Town Plays." The Cambridge Companion to Medieval English Theatre. Ed. Richard Beadle. Cambridge: Cambridge University Press, 1994. 163-210. Print.

Foucault, Michel. "Truth and Power." Power/Knowledge: Selected Interviews and Other Writings, 1972-1977. Ed. Colin Gordon. Trans. Colin Gordon et al. New York: Pantheon Books, 1980. 113-33. Print.

Gibson, Gail McMurray. "Bury St. Edmunds, Lydgate, and the N-Town Cycle.” Speculum 56.1 (Jan. 1981): 56-90. Print.

Gorringe, Timothy J. “Atonement." The Blackwell Companion to Political Theology. Ed. Peter Scott and William T. Cavanaugh. Malden, MA: Blackwell, 2004. 363-76. Print.

The Hammer of Witches: A Complete Translation of the Malleus Maleficarum. Trans. Christopher S. Mackay. Cambridge: Cambridge University Press, 2009. Print.

Jantzen, Grace. "Feminism in the Philosophy of Religion." Companion Encyclopedia of Theology. 1995. Ed. Peter Byrne and Leslie Houlden. London: Routledge, 2003. 490-508. Print.

John of Salisbury. The Statesman's Book of John of Salisbury, Being the Fourth, Fifth, and Sixth Books, and Selections from the Seventh and Eighth Books, of the Policraticus. 1927. Trans. John Dickinson. New York: Russell \& Russell, 1963. Print.

Kantorowicz, Ernst H. The King's Two Bodies: A Study in Mediaeval Political Theology. 1957. Princeton: Princeton University Press, 1997. Print.

Lambert, Malcolm D. The Cathars. Malden, MA: Blackwell. 1998. Print.

Lumiansky, R. M., and David Mills, eds. The Chester Mystery Cycle. Vol. 1. London: Oxford University Press. 1974. Print. EETS S.S. 3.

Middle English Dictionary. Ann Arbor: University of Michigan Press, 2001. Print.

Mirk, John. Festial. The Longman Anthology of British Literature. Ed. David Damrosch and Kevin J. H. Dettmar. 3rd ed. Vol. 1. New York: Pearson, 2006. 564-66. Print.

NeCastro, Gerard, ed. The N-Town Cycle. From Stage to Page: Medieval and Renaissance Drama. University of Maine at Machias, 2007. Web. 18 Mar. 2008.

The New King James Bible. Nashville: Thomas Nelson, 1984. Print.

Parallel Latin Vulgate Bible and Douay-Rheims Bible and King James Bible. Mental Systems. N.d. Web. 28 Feb. 2008.

Placher, William C. A History of Christian Theology: An Introduction. Philadelphia: Westminster Press, 1983. Print.

Polinska, Wioleta. “In Woman's Image: An Iconography for God." Feminist Theology 13.1 (2004): 40-61. Print.

Prosser, Diane Louise McDonald. Transgressive Corporeality: The Body, Poststructuralism, and the Theological Imagination. Albany: State University of New York Press, 1995. Print.

Ross, Ellen M. The Grief of God: Images of the Suffering Jesus in Late Medieval England. New York: Oxford University Press, 1997. Print.

Schaff, Philip, ed. The Creeds of the Greek and Latin Churches. 6th ed. New York: Harper and Row, 1905. Print. Vol. 2 of The Creeds of Christendom: With a History and Critical Notes. 3 vols.

Shakespeare, William. Hamlet. Ed. Ann Thomson and Neil Taylor. London: Arden Shakespeare, 2006. Print. Arden Shakespeare. Third Series.

Spector, Stephen. The N-Town Play: Cotton MS Vespasian D. 8. V. 1. Oxford: Oxford University Press, 1991. Print. EETS S.S. 11. 
Sugano, Douglas, ed. The N-Town Plays. Kalamazoo: Medieval Institute Publications, 2007. Medieval Institute Publications, Western Michigan University, Kalamazoo, in association with the University of Rochester. Web. 16 Jan. 2009. TEAMS Middle English Texts Series.

Van Engen, John. "The Christian Middle Ages as an Historiographical Problem." American Historical Review 91.3 (1986): 519-52. Print.

Weir, Lorna. "The Concept of Truth Regime." Canadian Journal of Sociology 33.2 (2008): 36789. Print.

Wenzel, Siegfried. Latin Sermon Collections from Later Medieval England: Orthodox Preaching in the Age of Wyclif. Cambridge: Cambridge University Press, 2005. Print. 